Article

\title{
Company Reputation, Implied Cost of Capital and Tax Avoidance: Evidence from Korea
}

\author{
Imhyeon Kim ${ }^{1}$, Jinsoo Kim ${ }^{2, *}$ and Jeongyeon Kang ${ }^{3}$ \\ 1 Department of Accounting, Daegu University, 201 Daegudae-ro, Gyeongsan-si 38453, Korea; \\ hsbkih@daegu.ac.kr \\ 2 Department of Accounting, Jeju National University, 102 Jejudaehak-ro, Jeju-si 63243, Korea \\ 3 College of Global Business, Sun Moon University, 70, 221 Sunmoon-ro, Tangjeong-myeon, \\ Asan-si 31460, Korea; jykang@sunmoon.ac.kr \\ * Correspondence: jskim01@jejunu.ac.kr
}

Received: 28 September 2020; Accepted: 27 November 2020; Published: 30 November 2020

\begin{abstract}
This study aims to investigate the relationship between company reputation and the implied cost of capital in Korean companies from 2003 to 2016, based on research by Cao et al. (2015). In addition, we would like to examine the effect of tax avoidance. Company reputation increases corporate sustainability and enables sustainable management. In this study, Brandstock Top Index (BSTI), which represents Korea's top 100 brands, was used as an interest variable representing company reputation. To examine the relationship between company reputation and implied cost of capital, the multiple linear regression analysis was conducted using various measures of implied cost of capital as a dependent variable. As a result of empirical analysis, company reputation and implied cost of capital showed a significant negative relationship. The higher the company's reputation, the less information asymmetry in the stock market, indicating that the implied cost of capital decreases. A significant negative relationship between company reputation and implied cost of capital was not found in a group that was aggressive in tax avoidance. The contributions of this study are as follows. First, we presented the empirical result that company reputation and implied cost of capital were negatively related in Korea. It showed empirically the importance of company reputation in the Korean stock market. Second, in addition to the relationship between company reputation and implied cost of capital, prior research was expanded considering tax avoidance.
\end{abstract}

Keywords: company reputation; sustainability management; implied cost of capital; tax avoidance

\section{Introduction}

According to the theory of economics related to reputation, reputation plays an important role in determining behavior (Wilson 1985) [1]. Company reputation increases corporate sustainability and enables sustainable management. The recent rapid changes surrounding the business environment draw attention to corporate sustainability management. Numerous companies use sustainability as an indicator of corporate management, and thus strive to increase their company reputation. From a consumer's point of view, we will examine the relationship between corporate reputation and cost of capital by using the brand value representing sustainability. Previous studies have suggested that the reputation of a company influences the role of auditors and financial analysts (Lacker and Richardson, 2004 [2]; Jackson, 2005 [3]; Cowen et al., 2006 [4]). Company reputation affects a company's debt financing and capital financing costs (Anginer et al., 2015 [5]; Cao et al., 2015 [6]).

This study aims to examine the relationship between company reputation and implied cost of capital. In addition, we would like to examine the effect of tax avoidance. The higher the company's reputation, the lower the implied cost of capital. Reputable companies focus on product quality and 
innovation to increase brand value. It is expected that information asymmetry among investors will decrease as efforts are made to increase the interests of shareholders. If the company's reputation is good, it can be expected that the capital cost will be low as investors' perception increases and liquidity increases. Companies with high reputations are expected to report financial reports to reduce information asymmetry among investors, resulting in lower capital costs. Therefore, it was expected that company reputation and implied cost of capital would be negatively related.

The negative relationship between company reputation and implied cost of capital is expected to vary depending on the degree of tax avoidance. Aggressive tax avoidance causes the opacity of the information environment and creates information asymmetry related to company reputation among investors (Balakrishnan et al., 2019 [7]). Therefore, it was expected that the relationship between company reputation and implied cost of capital would be different in an active tax avoidance group.

This study analyzed the effect of tax avoidance on the relationship between company reputation and implied cost of capital for listed companies in Korea from 2003 to 2016. The company reputation used the Brandstock Top Index (BSTI), which represents Korea's Top 100 Brands. Korea's Top 100 Brands is a system in which Brandstock developed a BSTI model that directly reflects consumers' evaluations, and is certified as a "Korea Top 100 Brand" based on the survey results. It is the only brand valuation certification system in Korea that selects and announces top 100 brands with high BSTI scores. The implied cost of capital is the PEG and MPEG models proposed by Easton (2004) [8], the GM model presented by Gode and Mohanram (2003) [9] and the variables that measured the average value of the three measurements were used. Tax avoidance was measured by cash effective tax rate (CASH ETR). In this study, the hypothesis was verified through multiple regression analysis using the implied cost of capital as the dependent variable and the company reputation as the variable of interest. Multiple regression analysis has the advantage of examining the relationship between the variable of interest and the dependent variable after controlling the effects of other variables. Many studies use multiple regression analysis for hypothesis testing. Since regression analysis makes assumptions, there are weaknesses that can be used after testing the assumptions. In this study, multiple regression analysis was performed after verifying the assumptions related to regression analysis. A study setting that can clearly compare the implied capital cost of the group with company reputation and the group without company reputation was constructed using the variable of interest as an indicator variable.

As a result of empirical analysis, company reputation and implied cost of capital showed a significant negative relationship. The higher the company's reputation, the less information asymmetry in the stock market, indicating that the implied cost of capital decreases. Significant negative relationship between company reputation and implied cost of capital was not found in a group that was aggressive in tax avoidance. This is interpreted as weakening the significant negative relationship between company reputation and implied capital costs due to aggressive tax avoidance that creates opacity in the information environment and creates information asymmetry related to corporate reputation.

The contributions and limitations of this study are as follows. First, in the context of lack of research in Korea that looked at the relationship between company reputation and implied cost of capital, we presented the empirical result that company reputation and implied cost of capital are negatively related. It is expected to provide useful information for follow-up studies by empirically showing the importance of company reputation in the stock market. Second, in addition to the use of Korean companies in the empirical analysis, the relationship between company reputation and implied cost of capital was additionally verified by dividing into active tax avoidance group and non-tax avoidance group to differentiate it from the study of Cao et al. (2015) [6]. Prior studies have been expanded in consideration of tax avoidance in relation to company reputation and implied cost of capital. The hypothesis we looked at further was not conducted in other studies and was not validated in previous studies. It shows that the relationship between company reputation and implied cost of capital can be changed according to tax avoidance. Third, it demonstrates the benefits that companies can achieve through sustainable management by maintaining a good reputation. Suggesting ways to increase brand value for financing to management and board of directors. 
The composition of this paper is as follows. In Section 2, the research hypothesis is set based on previous research. Section 3 designs a research model to test the hypothesis and describes the main variables. Section 4 presents the results of empirical analysis, and, finally, Section 5 summarizes the research results and presents the contribution points and limitations of this study.

\section{Literature Review and Research Hypotheses}

\subsection{Literature}

Anginer et al. (2015) [5] and Cao et al. (2015) [6] exist as representative studies examining company reputation and cost of capital. Anginer et al. (2015) [5] studied the relationship between corporate reputation and cost of debt capital. The results showed that there was a significant negative relationship between company reputation and cost of debt capital. It was interpreted that the higher the company's reputation, the lower the cost of debt financing, so that financing was useful. Cao et al. (2015) [6] examined the relationship between company reputation and cost of equity capital. As a result of the analysis, it was suggested that company reputation and capital cost are negatively related. It was interpreted that the higher the company's reputation, the lower the cost of equity financing, which is useful for financing. In summary, the higher the reputation of the company, the lower the funding cost.

The following study looked at the relationship between tax avoidance and cost of capital. Goh et al. (2016) [10] analyzed the relationship between tax avoidance and cost of capital based on the Lambert et al. (2007) [11] model. As the tax avoidance decreased, the capital cost of the company decreased. Tax avoidance increases the opacity of the corporate information environment (Balakrishnan et al., 2019 [7]) and compromises the quality and accuracy of accounting information (Frank et al., 2009 [12]). As such, investors' uncertainty about the company's future cash flows increases, increasing shareholders' required returns. In addition, it was found that the better the external monitoring effect or the better the quality of accounting information, the weaker the positive relationship between tax avoidance and cost of capital. Cook et al. (2017) [13] also verified the relationship between tax avoidance and cost of capital. As a result of the study, investors showed different perceptions according to the level of tax avoidance. In the case of companies with low levels of tax avoidance, the increase in tax avoidance led to a decrease in the cost of capital, while those in the group with high levels of tax avoidance increased the cost of capital.

Graham et al. (2014) [14] conducted a survey on how management perceived company reputation. It was shown that $69 \%$ of executives showed that company reputation is important. It appears that executives do not actively plan for tax due to the reputation of the company. Gallemore et al. (2014) [15] studied the relationship between tax avoidance and reputation costs in 118 companies with tax havens. It was expected that companies accused of tax havens would bear reputation costs. As a result of various verifications, there was no evidence that reputational costs were incurred due to tax shelter. Dyreng et al. (2016) [16] empirically analyzed the relationship between reputation cost and tax avoidance. As a result of the analysis, it was found that the reputation cost and tax avoidance were negatively related. This translates to a decrease in tax avoidance due to public surveillance of the location of subsidiaries in the UK. Austin and Wilson (2017) [17] examined the relationship between brand value and tax avoidance. As a result of analysis, the higher the brand value, the lower the tax avoidance level. It was interpreted that the higher the exposure to reputation among consumers, the lower the level of tax avoidance is maintained because the media and tax authorities do not want to scrutinize.

Choi (2012) [18] and Lim (2011) [19] are representative studies examining the effects of capital cost using Korean data. Choi (2012) [18] examined the relationship between the level of ethical commitment and the implied cost of capital in Korean companies. In the Korean stock market, it was confirmed that there was a significant negative association between the degree of companies' ethical commitment and the implied cost of capital. This is a study result showing that business ethics is one of the important 
elements of firm valuation. This study differs from that of Choi (2012) [18] in that company reputation is the main variable of interest. Lim (2011) [19] focused on the effect of tax avoidance on debt cost. He found a negative relationship between tax avoidance and debt costs for Korean companies. It is interpreted that tax avoidance reduces debt costs through trade-offs. This study differs from the study of Lim (2011) [19] in that it examines the effect of tax avoidance on the relationship between company reputation and implied cost of capital.

Goodwill can be viewed as a variable related to company reputation. Prestige, reputation, brand and image simply "enterprise goodwill" as an economic phenomenon has attracted attention of economic experts since the nineteenth century. Podhorska et al. (2019) [20] conducted a study with the purpose of identifying individual goodwill indicators in the Slovak Republic. Efforts were made to obtain potential indicators for goodwill by using 15 individual indicators. Podhorska et al. (2019) [21] used the financial statements of Slovak companies in 2015 and the financial statements of Slovak and Czech companies in 2015 and 2016 to deal with the evaluation and verification of goodwill of companies. As a result of the study, it was suggested that there is a need to identify the determinants of creating goodwill of individual companies. Kliestik (2018) [22] identified the source of corporate goodwill creation based on residual income in the Slovak Republic. It was confirmed that the major sources of corporate goodwill creation include return on equity, net income previous year, retained earning prior years, valuable rights, marketing costs and investments to the plant.

\subsection{Hypothesis Development}

Based on the contents presented by Cao et al. (2015) [6], this study predicted that the company reputation and implied cost of capital are negatively related for the following reasons. First, companies seek to increase their reputation in the market and strive to increase the value of the brands they launch. Companies with high company reputation are expected to reduce information asymmetry among the company's stakeholders as they strive to increase the profits of shareholders by paying attention to product quality and innovation processes to increase brand value. Since information related to a company's reputation is useful to investors and the public, every year the information asymmetry will decrease and the cost of capital will be low. Second, if the company's reputation is high, investors' perceptions are better and liquidity is higher, so cost of capital is expected to be lower. Stocks with low investor awareness are diversified in risk. Markets with incomplete information require higher expected returns to compensate for certain risks (Merton 1987 [23]). On the other hand, a company with a high reputation by having products with high brand value to investors and the public will be highly recognized by investors. Therefore, a company with high reputation is expected to have low capital cost because it can efficiently manage risk. Third, companies with high reputation report high-quality financial reports (Cao et al., 2012 [24]). High-quality financial reporting is expected to reduce capital costs by reducing information asymmetry (Francis et al., 2004 [25]).

Hypothesis 1 (H1). Company reputation and implied cost of capital are negatively related.

Goh et al. (2016) [10] presented the empirical result that tax avoidance and capital cost are positively related. Aggressive tax avoidance not only increases the opacity of the company's information environment, but also involves aggressive financial reporting that undermines the quality and accuracy of accounting information. This increases investor uncertainty about the company's future cash flows. Aggressive tax avoidance accompanies the opacity of the information environment, causing information asymmetry among investors (Balakrishnan et al., 2019 [7]). Company reputation is influenced by tax planning. Graham et al. (2014) [14] presented the results of a survey that managers do not actively pursue tax planning because they value company reputation.

From the following two perspectives, tax avoidance was expected to affect the negative relationship between company reputation and implied cost of capital. First, the reputation of a company is affected by tax planning, and there is a possibility that aggressive tax avoidance will negatively affect the 
company's reputation (Graham et al., 2014 [14]). If caught in tax avoidance, there is a company's reputation cost. If ex-post tax avoidance acts are caught, it has a negative effect on company reputation, but it is difficult to clearly explain how aggressive tax avoidance itself affects company reputation. However, when looking at how tax avoidance affects the relationship between company reputation and cost of capital, aggressive tax avoidance causes opacity in the information environment and asymmetry among investors. Therefore, it was expected that aggressive tax avoidance would cause information asymmetry related to company reputation and affect capital costs. Second, reputable companies strive to provide high-quality financial reporting (Cao et al., 2012 [24]). In the case of aggressive tax avoidance, there is a possibility of aggressive financial reporting even if the quality of accounting information is impaired, so it is expected that aggressive tax avoidance will cause information asymmetry related to company reputation and affect capital costs.

This study predicted that aggressive tax avoidance would cause information asymmetry related to the company's reputation, weakening the negative relationship between company reputation and implied cost of capital. Therefore, we suggest our next hypothesis as follows:

Hypothesis 2 (H2). Companies that are aggressive in tax avoidance have a weak negative relationship between company reputation and implied cost of capital than those that are not.

\section{Research Design}

\subsection{Measuring Variables}

\subsubsection{Company Reputation}

The brand value of the company was used as a variable representing the company's reputation. The brand value is based on the selection history of the Brandstock Top Index, which represents the top 100 brands in Korea. Korea's top 100 brands are measured by the BSTI model, where brand stock is directly reflected in consumer evaluation. Based on the results of the survey, it is the system to certify as the " 100 best brands in Korea" and it is the only brand value evaluation certification system in Korea that selects and announces the top 100 brands with the highest BSTI scores.

According to the world's top 100 brands announced by Interbrand, a world-renowned brand consulting group, Coca-Cola's brand value ranked No. 1 for 11 consecutive years at $\$ 77.4$ billion. The brand values of Google and Apple were 4th and 17th, and the brand value of Samsung Electronics in Korea was \$19.4 billion, ranking 19th, two levels below Apple. The top 100 Korean brands are selected based on the brand value evaluation model BSTI as a local brand index targeting brands distributed in Korea. BSTI is calculated from stock exchange data and consumer survey data for brand panels. The top 100 brands in Korea are presented every quarter, and in this study, research was conducted using the final aggregated data every year.

Looking at the 1st to 10th among the top 100 brands in 2016, Samsung Galaxy in 1st place, E-mart in 2nd place, Kakao Talk in 3rd place, Naver in 4th place, KB Kookmin Bank in 5th place, Incheon International Airport in 6th place, 7th Shinhan Card ranked 8th, Lotte World Adventure ranked 8th, Chamisul 9th and Lotte Department Store 10th. In this study, REPUTATION was set as a variable of interest to measure corporate reputation, and if products belonging to 100 brands were classified as 1 or 0 .

\subsubsection{Implied Cost of Capital}

In this study, four methods were used to measure the implied cost of capital. The implied cost of capital is the required rate of return according to the level of risk recognized by investors, and is the cost of equity capital measured as future profits at the current price. In this study, the cost of equity capital was unified as the cost of intrinsic capital. As a method for measuring the implied cost of capital, two capital cost estimates (hereinafter referred to as PEG and MPEG models) provided by 
Easton (2004) [8] and capital cost estimates (hereinafter referred to as GM models) proposed by Gode and Mohanram (2003) [9] were used. Additionally, the average values of the three measurements were also used.

The PEG model was measured based on the growth potential of the stock price return without considering dividends based on the abnormal profit growth valuation model. The PEG model is an estimate of the cost of capital presented under the assumption that the non-expected growth rate of accounting profit is 0 and dividend per share is 0 after period 1, as shown in Equation (1).

$$
C O C_{p e g}=\sqrt{\frac{\left(F E P S_{t+2}-F E P S_{t+1}\right)}{P_{t}}}
$$

where $F E P S_{t+1}$ and $F E P S_{t+2}$ indicate estimated earnings per share after 1 and 2 years, respectively. $P_{t}$ is price per share at the present time.

The MPEG model is a special form of the Ohlson and Juettner-Nauroth (2005) [26] model, which is a modification of the PEG model in consideration of dividends. The MPEG model is as shown in Equation (1), and it is meaningful that it reflects future values such as the forecast of earnings per share and the forecast of dividends per share. It can be seen that in the MPEG model, when the dividend per share is 0 , it is the same as the estimate of the PEG model.

$$
C O C_{\text {mpeg }}=\frac{D P S_{t+1}+\sqrt{D P S_{t+1}^{2}+4 \times P_{t} \times\left(F E P S_{t+2}-F E P S_{t+1}\right)}}{2 P_{t}}
$$

where $D P S_{t+1}$ is stock dividend forecast after one year.

The GM model is based on the excess profit growth model proposed by Ohlson and Juettner-Nauroth (2005) [26] and estimates the cost of equity capital as shown in the following Equation (3). The GM model used $D P S_{t}$, which represents the actual dividend in place of $D P S_{t+1}$ in the MPEG model and the GM model.

$$
\begin{gathered}
C O C_{G M}=\mathrm{A}+\sqrt{A^{2}+\left(\frac{F E P S_{1}}{P_{1}}\right) \times\left(g_{2}-\left(r_{f}-0.03\right)\right)} \\
\mathrm{A}=\frac{\left(r_{f}-0.03\right)}{2}+\frac{D P S_{t+1}}{2 P_{t}} \\
g_{2}=\frac{F E P S_{t+2}}{F E P S_{t+1}}-1
\end{gathered}
$$

here $r_{f}$ is risk free interest rate.

\subsubsection{Tax Avoidance}

The tax avoidance measures used in tax avoidance-related studies vary among researchers. Dyreng et al. (2008) [27] defined tax avoidance as explicit tax reduction. This study also defined tax avoidance as any action to reduce explicit taxes according to Dyreng et al. (2008) [27]. Specifically, tax avoidance was measured by the company's cash effective tax rate, and was calculated by dividing corporate tax payments by pretax profit. CASH ETR uses the actual corporate tax payment, so it has the advantage of evaluating the actual tax burden. This study was analyzed by dividing into an aggressive tax avoidance group and a non-tax avoidance group. According to Donohoe and Knechel (2014) [28], if the CASH ETR was the lowest quintile, it was classified as an aggressive tax avoidance group. 


\subsection{Research Model}

This study analyzes the relationship between company reputation and implied cost of capital. In this study, the hypothesis was verified through multiple regression analysis using the implied cost of capital as the dependent variable and the company reputation as the variable of interest. Multiple regression analysis has the advantage of examining the relationship between the variable of interest and the dependent variable after controlling the effects of other variables. Many studies use multiple regression analysis for hypothesis testing. Since regression analysis makes assumptions, there are weaknesses that can be used after testing the assumptions. In this study, multiple regression analysis was performed after verifying the assumptions related to regression analysis. The model looking at the relationship between company reputation and implied cost of capital is shown in Equation (6) below. If $\beta_{1}$, the coefficient of reputation, has a negative value, it means that a company with high reputation has a low implied cost of capital. In addition, in order to verify whether the relationship between company reputation and implied cost of capital varies depending on the degree of tax avoidance, the tax avoidance was divided into aggressive and non-aggressive groups.

$$
\begin{aligned}
& \mathrm{COC}_{i, t}=\beta_{0}+\beta_{1} \text { REPUTATION }_{i, t}+\beta_{2} \text { SIZE }_{i, t}+\beta_{3} L E V_{i, t}+\beta_{4} R O A_{i, t}+\beta_{5} M T B_{i, t} \\
& \quad+\beta_{6} \text { BETA }_{i, t}+\beta_{7} D A_{i, t}+\beta_{8} \text { FORN }_{i, t}+\beta_{9} \text { OWN }_{i, t}+\sum \text { YEAR }+\sum I N D+\varepsilon_{i, t}
\end{aligned}
$$

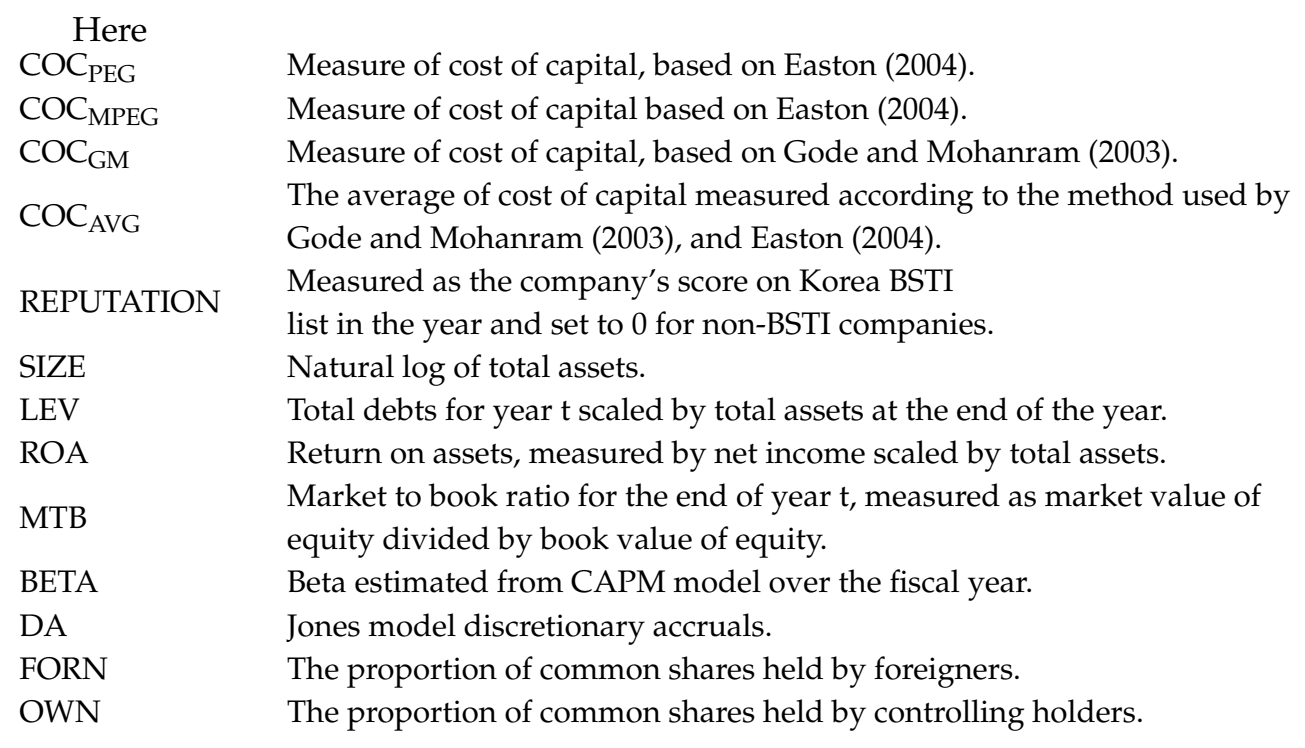

As the dependent variable of model (1), the average value of the model was used in addition to the PEG model, MPEG model and GM model as the implied cost of capital. The variable of interest in model (1) is REPUTATION, which represents the company's reputation. The hypothesis was verified through the coefficient of REPUTATION.

Control variables were set based on prior studies that looked at capital costs. SIZE and BETA are included to control corporate risk. MTB was added as a control variable because the higher the ratio of book value to market value means that the profitability of investment and management is efficient. The debt-to-equity ratio (LEV) was included in the model as a variable to control financial risk. The model includes the total asset return (ROA) representing the company's performance and the discretionary accrual (DA) representing the performance adjustment. In order to control the effect of the governance structure related to major shareholders and foreigners, the ownership ratio (OWN) and the foreign investor ratio (FORN) were controlled. Year and industry variables were included to control year and industry effects. 


\subsection{Sample Selection}

The sample used in this study is a listed company in Korea's securities market from 2003 to 2016. Financial statement settlement month is December. It targeted non-financial businesses. In order to secure the homogeneity of the sample companies according to the difference in the settlement month, the closing company was set in December. The financial industry was excluded from the analysis because the characteristics of financial information differed from other companies. We targeted companies that could use data from the Korean data database, FnGuide or TS2000. In order to estimate the implied cost of capital, this study targeted companies that could obtain financial analyst's forecast information from 2003 to 2016. In order to reduce the measurement error of CASH ETR in accordance with previous studies, companies with negative pre-tax profit were eliminated. After adjusting the CASH ETR to [0,1] for values outside 0 and 1, we divided groups that are aggressiveness in tax avoidance and those that are not. Brand value, an interest variable, is an indicator variable. Excluding the brand value and tax avoidance variables, the extreme values of the other variables were winsorized at the top and bottom $1 \%$ level. The year sample is shown in Table 1, and the number of firm-year observations used in the analysis was 1753.

Table 1. Classification of samples according to company reputation.

\begin{tabular}{cccc}
\hline Year & Reputation $=\mathbf{0}$ & Reputation $=\mathbf{1}$ & Total \\
\hline 2003 & 91 & 11 & 102 \\
2004 & 95 & 17 & 112 \\
2005 & 85 & 17 & 102 \\
2006 & 97 & 14 & 111 \\
2007 & 126 & 14 & 140 \\
2008 & 97 & 16 & 113 \\
2009 & 127 & 18 & 145 \\
2010 & 125 & 17 & 142 \\
2011 & 127 & 19 & 146 \\
2012 & 81 & 16 & 97 \\
2013 & 107 & 15 & 122 \\
2014 & 122 & 16 & 138 \\
2015 & 123 & 19 & 142 \\
2016 & 119 & 22 & 141 \\
Total & 1522 & 231 & 1753 \\
\hline
\end{tabular}

\section{Empirical Results}

\subsection{Descriptive Statistics}

Table 2 shows the descriptive statistics of the main variables. The mean (median) of implied cost of capital estimated using the PEG model, MPEG model and GM model were 13.2\% (11.8\%), $14.2 \%$ (12.7\%) and $14.1 \%(12.7 \%)$, respectively. The mean (median) of the implied cost of capital measured using the average of the three models was $13.8 \%(12.5 \%)$. The companies used in the analysis have a capital cost of about $14 \%$, which means that the required rate of return for capital market participants is about $14 \%$. Companies with high reputations, measured by the BSTI, accounted for $13.2 \%$ of the total sample. The CASH ETR, a measure of tax avoidance, had a mean (median) of $23.9 \%(22.4 \%)$. The companies used in the analysis seem to pay about $23 \%$ of the pre-tax profit as corporate tax. 
Table 2. Descriptive statistics.

\begin{tabular}{cccccccc}
\hline Variables & Mean & Std. Dev. & Min & Q1 & Median & Q3 & Max \\
\hline COC $_{\text {PEG }}$ & 0.132 & 0.062 & 0.038 & 0.090 & 0.118 & 0.160 & 0.370 \\
COC $_{\text {MPEG }}$ & 0.142 & 0.064 & 0.044 & 0.098 & 0.127 & 0.170 & 0.383 \\
COC $_{\text {GM }}$ & 0.141 & 0.063 & 0.043 & 0.098 & 0.127 & 0.170 & 0.382 \\
COC $_{\text {AVG }}$ & 0.138 & 0.063 & 0.043 & 0.096 & 0.125 & 0.166 & 0.377 \\
REPUTTION $_{\text {CASH ETR }}$ & 0.132 & 0.338 & 0.000 & 0.000 & 0.000 & 0.000 & 1.000 \\
SIZE & 0.239 & 0.199 & 0.000 & 0.121 & 0.224 & 0.298 & 1.000 \\
LEV & 21.067 & 1.510 & 18.301 & 19.949 & 20.942 & 22.110 & 24.840 \\
ROA & 0.429 & 0.175 & 0.084 & 0.288 & 0.438 & 0.565 & 0.805 \\
MTB & 0.071 & 0.052 & 0.001 & 0.032 & 0.060 & 0.098 & 0.255 \\
BETA & 1.662 & 1.437 & 0.264 & 0.791 & 1.221 & 1.950 & 8.575 \\
DA & 0.849 & 0.382 & 0.093 & 0.568 & 0.826 & 1.120 & 1.735 \\
FORN & 0.000 & 0.063 & -0.186 & -0.037 & -0.003 & 0.035 & 0.187 \\
OWN & 0.205 & 0.163 & 0.000 & 0.069 & 0.164 & 0.313 & 0.689 \\
\hline
\end{tabular}

Variable Definitions: $\mathrm{COC}_{\mathrm{PEG}}=$ Measure of implied cost of capital, based on Easton (2004) [8]. $\mathrm{COC}_{\mathrm{MPEG}}=$ Measure of implied cost of capital based on Easton (2004) [8]. COC $_{\mathrm{GM}}=$ Measure of implied cost of capital, based on Gode and Mohanram (2003) [9]. COC $\mathrm{CEE}_{\mathrm{AEG}}=$ The average of implied cost of capital from Gode and Mohanram (2003) [9], and Easton (2004) [8]. REPUTATION = Measured as the company's score on Korea BrandStock Top Index (BSTI) list in the year and set to 0 for non-BSTI companies; CASH ETR $=$ Cash tax paid divided by pretax income for year $\mathrm{t}$. SIZE $=$ Natural $\log$ of total assets. LEV $=$ Total debts for year $\mathrm{t}$ scaled by total assets at the end of the year. $\mathrm{ROA}=$ Return on assets, measured by net income scaled by total assets. MTB $=$ Market to book ratio for the end of year $t$, measured as market value of equity divided by book value of equity. BETA = Beta estimated from CAPM model over the fiscal year. DA = Jones model discretionary accruals. FORN $=$ The proportion of common shares held by foreigners. OWN $=$ The proportion of common shares held by controlling holders .

Table 3 is the result of analyzing the correlation between variables. The correlations in Table 3 between REPUTITION and the four measures of implied cost of equity (COCPEG, COCMPEG, COCGM and COCAVG) are significantly negative, which suggests that company reputation is associated with a lower cost of equity. The correlation between COCAVG, the average implied cost of capital, and control variables is as follows. LEV, BETA and DA showed a significant positive relationship with COCAVG. On the other hand, SIZE, ROA, MTB and FORN showed a significant negative relationship with COCAVG. The correlation between implied cost of equity and other control variables is also largely consistent with prior literature in Korea. Multicollinearity problems can arise in regression analysis due to the high correlation between variables. To confirm multicollinearity, the variance inflation factor (VIF) of all regression models used in the analysis were checked. VIF was less than 10, indicating that there was no big problem with multicollinearity. As a result of verifying the assumption of homoscedasticity and normality in relation to the regression analysis, it was judged that there was no major problem in the analysis because the assumption was not violated. 
Table 3. Pearson (Spearman) correlation matrix.

\begin{tabular}{|c|c|c|c|c|c|c|c|c|c|c|c|c|c|c|}
\hline & $\mathrm{COC}_{\mathrm{PEG}}$ & $\mathrm{COC}_{\text {MPEG }}$ & $\mathrm{COC}_{\mathrm{GM}}$ & $\mathrm{COC}_{\mathrm{AVG}}$ & REPUTATION & CASH ETR & SIZE & LEV & ROA & MTB & BETA & DA & FORN & OWN \\
\hline $\mathrm{COC}_{\mathrm{PEG}}$ & & 0.991 & 0.989 & 0.996 & -0.175 & 0.005 & -0.228 & 0.254 & -0.170 & -0.259 & 0.068 & 0.071 & -0.224 & 0.022 \\
\hline $\mathrm{COC}_{\mathrm{MPEG}}$ & 0.985 & & 0.997 & 0.999 & -0.181 & 0.004 & -0.244 & 0.241 & -0.158 & -0.286 & 0.038 & 0.066 & -0.215 & 0.039 \\
\hline $\mathrm{COC}_{\mathrm{GM}}$ & 0.985 & 0.997 & & 0.998 & -0.181 & 0.000 & -0.236 & 0.247 & -0.161 & -0.281 & 0.046 & 0.064 & -0.214 & 0.036 \\
\hline $\mathrm{COC}_{\mathrm{AVG}}$ & 0.993 & 0.998 & 0.998 & & -0.180 & 0.003 & -0.237 & 0.248 & -0.163 & -0.276 & 0.051 & 0.067 & -0.218 & 0.032 \\
\hline REPUTATION & -0.179 & -0.188 & -0.187 & -0.185 & & -0.011 & 0.349 & -0.004 & 0.127 & 0.130 & -0.062 & -0.113 & 0.395 & -0.154 \\
\hline CASH ETR & -0.049 & -0.040 & -0.046 & -0.045 & 0.001 & & -0.019 & 0.027 & -0.184 & 0.017 & -0.014 & -0.036 & 0.011 & 0.015 \\
\hline SIZE & -0.208 & -0.231 & -0.223 & -0.221 & 0.333 & -0.060 & & 0.292 & -0.121 & 0.023 & 0.287 & -0.080 & 0.403 & -0.203 \\
\hline LEV & 0.265 & 0.255 & 0.258 & 0.261 & -0.006 & -0.026 & 0.324 & & -0.362 & 0.037 & 0.252 & 0.015 & -0.165 & -0.043 \\
\hline $\mathrm{ROA}$ & -0.189 & -0.171 & -0.172 & -0.178 & 0.108 & -0.082 & -0.169 & -0.390 & & 0.419 & -0.046 & 0.081 & 0.271 & -0.036 \\
\hline MTB & -0.307 & -0.353 & -0.339 & -0.334 & 0.133 & 0.043 & 0.080 & 0.006 & 0.415 & & 0.024 & -0.030 & 0.266 & -0.103 \\
\hline BETA & 0.083 & 0.051 & 0.057 & 0.063 & -0.062 & -0.072 & 0.294 & 0.251 & -0.079 & 0.056 & & 0.055 & -0.021 & -0.201 \\
\hline DA & 0.064 & 0.056 & 0.052 & 0.057 & -0.137 & -0.056 & -0.071 & 0.023 & 0.034 & -0.062 & 0.060 & & -0.100 & 0.055 \\
\hline FORN & -0.265 & -0.265 & -0.257 & -0.263 & 0.366 & 0.085 & 0.436 & -0.139 & 0.267 & 0.284 & -0.016 & -0.094 & & -0.289 \\
\hline OWN & 0.031 & 0.046 & 0.038 & 0.038 & -0.154 & 0.017 & -0.187 & -0.046 & -0.020 & -0.151 & -0.216 & 0.045 & -0.317 & \\
\hline
\end{tabular}

(1) Please see Table 2 for variable definitions. (2) This table presents Pearson (Spearman) correlations. Coefficients shown in bold are significant at $p<0.05$ (two-tailed test). 


\subsection{Empirical Results}

\subsubsection{Main Results}

This section reports the results for the test of $\mathrm{H} 1$ that examines the association between company reputation and implied cost of equity. As shown in Table 4, company reputation was found to be significantly negatively related to all four implied cost of capital measures (t-statistic $-1.76,-2.13$, -2.20 and -2.04 for COCPEG, COCMPEG, COCGM and COCAVG, respectively). This is the result of supporting Hypothesis 1. Research results can be interpreted from the following perspectives. First, information related to the reputation of a company is useful to investors and the public, thus reducing information asymmetry and lowering capital costs. Second, it is interpreted that the company's reputation has increased liquidity, lowering capital costs. Lastly, the reputable companies report high-quality financial, reducing information asymmetry and lowering capital costs.

Looking at the control variables, SIZE and MTB showed a significant negative relationship with the implied cost of capital. This means that the larger the company size, the greater market to book ratio, the lower the implied cost of capital. LEV showed a significant positive correlation with the implied cost of capital. This means that the higher the debt ratio, the higher the implied cost of capital. As a result of examining the relationship between the control variables and the implied cost of capital, there was no difference from the previous study.

Table 4. The effect of company reputation on the implied cost of equity (H1).

\begin{tabular}{|c|c|c|c|c|c|c|c|c|c|c|c|c|}
\hline \multirow{2}{*}{$\begin{array}{l}\text { Variables } \\
\text { Intercept }\end{array}$} & \multicolumn{3}{|c|}{$\mathrm{COC}_{\mathrm{PEG}}$} & \multicolumn{3}{|c|}{$\mathrm{COC}_{\text {MPEG }}$} & \multicolumn{3}{|c|}{$\mathrm{COC}_{\mathrm{GM}}$} & \multicolumn{3}{|c|}{$\mathrm{COC}_{\mathrm{AVG}}$} \\
\hline & $\begin{array}{c}\text { Estimate } \\
0.332\end{array}$ & 12.69 & $* * *$ & $\begin{array}{c}\text { Estimate } \\
0.353\end{array}$ & 13.35 & $* * *$ & $\begin{array}{c}\text { Estimate } \\
0.345\end{array}$ & 13.05 & $* * *$ & $\begin{array}{c}\text { Estimate } \\
0.343\end{array}$ & 13.07 & $* * *$ \\
\hline REPUTATION & -0.008 & -1.76 & * & -0.010 & -2.13 & $* *$ & -0.010 & -2.20 & $* *$ & -0.009 & -2.04 & ** \\
\hline SIZE & -0.013 & -10.99 & $* * *$ & -0.014 & -11.26 & $* * *$ & -0.013 & -11.04 & $* * *$ & -0.013 & -11.13 & $* * *$ \\
\hline LEV & 0.113 & 11.71 & $* * *$ & 0.118 & 12.01 & $* * *$ & 0.118 & 12.09 & $* * *$ & 0.116 & 11.97 & $* * *$ \\
\hline $\mathrm{ROA}$ & -0.027 & -0.84 & & -0.004 & -0.12 & & -0.009 & -0.26 & & -0.013 & -0.40 & \\
\hline MTB & -0.010 & -9.18 & $* * *$ & -0.012 & -10.63 & $* * *$ & -0.012 & -10.39 & $* * *$ & -0.011 & -10.10 & $* * *$ \\
\hline BETA & 0.007 & 1.73 & $*$ & 0.003 & 0.80 & & 0.004 & 0.91 & & 0.005 & 1.16 & \\
\hline $\mathrm{DA}$ & 0.021 & 1.00 & & 0.016 & 0.75 & & 0.014 & 0.67 & & 0.017 & 0.79 & \\
\hline FORN & 0.010 & 0.94 & & 0.017 & 1.64 & & 0.017 & 1.63 & & 0.016 & 1.43 & \\
\hline OWN & -0.007 & -0.72 & & 0.001 & 0.07 & & 0.000 & 0.02 & & -0.002 & -0.21 & \\
\hline Fixed effect & \multicolumn{12}{|c|}{ Industry and Year } \\
\hline Adj R2 & \multicolumn{3}{|c|}{0.273} & \multicolumn{3}{|c|}{0.294} & \multicolumn{3}{|c|}{0.290} & \multicolumn{3}{|c|}{0.287} \\
\hline $\mathrm{N}$ & \multicolumn{3}{|c|}{1753} & \multicolumn{3}{|c|}{1753} & \multicolumn{3}{|c|}{1753} & \multicolumn{3}{|c|}{1753} \\
\hline
\end{tabular}

(1) Please see Table 2 for variable definitions. (2) ${ }^{* * * * * *}$ and * Indicate statistical significance at the $0.01,0.05$ and 0.10 levels, respectively.

Table 5 shows the result of verifying the relationship between company reputation and implied cost of capital after the classification of the aggressive tax avoidance group and the non-aggressive tax avoidance group.

Panel A shows the relationship between company reputation and implied cost of capital in an aggressive tax avoidance group. As can be seen in Panel A of Table 5, company reputation was found to have no significant relationship with the four implied cost of capital measures (t-statistic -0.30 , $-0.25,-0.36$ and -0.30 for COCPEG, COCMPEG, COCGM and COCAVG, respectively). Panel B shows the relationship between company reputation and implied cost of capital in a non-aggressive tax avoidance group. As can be seen in Panel B of Table 5, company reputation was found to be significantly negatively related to all four implied cost of capital measures (t-statistic $-1.72,-2.15,-2.20$ and -2.04 for COCPEG, COCMPEG, COCGM and COCAVG, respectively). According to the analysis results of Panel A and Panel B, it appears to support Hypothesis 2. Aggressive tax avoidance lowered the quality of accounting information and caused information asymmetry related to the reputation of the company, resulting in lower capital costs. Aggressive tax avoidance is interpreted as causing information asymmetry related to the company's reputation, weakening the negative relationship between company reputation and implied capital costs. 
Table 5. The effect of company reputation on the implied cost of equity.

\begin{tabular}{|c|c|c|c|c|c|c|c|c|c|c|c|c|}
\hline \multicolumn{13}{|c|}{ Panel A: Aggressive Tax Avoidance Groups } \\
\hline \multirow{3}{*}{$\begin{array}{l}\text { Variables } \\
\text { Intercept }\end{array}$} & \multicolumn{3}{|c|}{$\mathrm{COC}_{\text {PEG }}$} & \multicolumn{3}{|c|}{$\mathrm{COC}_{\text {MPEG }}$} & \multicolumn{3}{|c|}{$\mathrm{COC}_{\mathrm{GM}}$} & \multicolumn{3}{|c|}{$\mathrm{COC}_{\mathrm{AVG}}$} \\
\hline & \multirow{2}{*}{$\begin{array}{c}\text { Estimate } \\
0.450\end{array}$} & \multicolumn{2}{|c|}{$\mathrm{t}$-Stat } & \multirow{2}{*}{$\begin{array}{c}\text { Estimate } \\
0.485\end{array}$} & \multicolumn{2}{|c|}{ t-Stat } & \multirow{2}{*}{$\begin{array}{c}\text { Estimate } \\
0.475\end{array}$} & \multicolumn{2}{|c|}{ t-Stat } & \multirow{2}{*}{$\begin{array}{c}\text { Estimate } \\
0.470\end{array}$} & \multicolumn{2}{|c|}{ t-Stat } \\
\hline & & 6.83 & $* * *$ & & 7.32 & $* * *$ & & 7.21 & $* * *$ & & 7.14 & $* * *$ \\
\hline REPUTATION & -0.004 & -0.30 & & -0.003 & -0.25 & & -0.004 & -0.36 & & -0.004 & -0.30 & \\
\hline SIZE & -0.018 & -6.20 & $* * *$ & -0.019 & -6.56 & $* * *$ & -0.019 & -6.50 & $* * *$ & -0.019 & -6.43 & $* * *$ \\
\hline LEV & 0.116 & 4.74 & $* * *$ & 0.119 & 4.82 & $* * *$ & 0.120 & 4.88 & $* * *$ & 0.118 & 4.82 & $* * *$ \\
\hline ROA & -0.055 & -0.80 & & -0.035 & -0.51 & & -0.044 & -0.65 & & -0.044 & -0.65 & \\
\hline MTB & -0.019 & -4.84 & $* * *$ & -0.022 & -5.45 & $* * *$ & -0.021 & -5.22 & $* * *$ & -0.021 & -5.18 & $* * *$ \\
\hline BETA & 0.010 & 0.95 & & 0.006 & 0.58 & & 0.007 & 0.60 & & 0.008 & 0.71 & \\
\hline DA & 0.018 & 0.39 & & 0.010 & 0.21 & & 0.011 & 0.24 & & 0.013 & 0.27 & \\
\hline FORN & 0.027 & 0.91 & & 0.037 & 1.24 & & 0.040 & 1.34 & & 0.035 & 1.17 & \\
\hline OWN & -0.051 & -2.16 & $* *$ & -0.045 & -1.91 & $*$ & -0.043 & -1.84 & $*$ & -0.047 & -1.98 & $* *$ \\
\hline Fixed effect & & & & & & Indu & ind Year & & & & & \\
\hline Adj R2 & & 0.293 & & & 0.305 & & & 0.306 & & & 0.301 & \\
\hline $\mathrm{N}$ & & 350 & & & 350 & & & 350 & & & 350 & \\
\hline
\end{tabular}


Table 5. Cont

\begin{tabular}{|c|c|c|c|c|c|c|c|c|c|c|c|c|}
\hline \multicolumn{13}{|c|}{ Panel B: Non-Aggressive Tax Avoidance Groups } \\
\hline \multirow{3}{*}{$\begin{array}{l}\text { Variables } \\
\text { Intercept }\end{array}$} & \multicolumn{3}{|c|}{$\mathrm{COC}_{\mathrm{PEG}}$} & \multicolumn{3}{|c|}{$\mathrm{COC}_{\text {MPEG }}$} & \multicolumn{3}{|c|}{$\mathrm{COC}_{\mathrm{GM}}$} & \multicolumn{3}{|c|}{$\mathrm{COC}_{\mathrm{AVG}}$} \\
\hline & \multirow{2}{*}{$\begin{array}{c}\text { Estimate } \\
0.309\end{array}$} & \multicolumn{2}{|c|}{$\mathrm{t}$-Stat } & \multirow{2}{*}{$\begin{array}{c}\text { Estimate } \\
0.326\end{array}$} & \multicolumn{2}{|c|}{ t-Stat } & \multirow{2}{*}{$\begin{array}{c}\text { Estimate } \\
0.318\end{array}$} & \multicolumn{2}{|c|}{ t-Stat } & \multirow{2}{*}{$\begin{array}{c}\text { Estimate } \\
0.318\end{array}$} & \multicolumn{2}{|c|}{ t-Stat } \\
\hline & & 10.78 & $* * *$ & & 11.22 & $* * *$ & & 10.95 & $* * *$ & & 11.02 & $* * *$ \\
\hline REPUTATION & -0.008 & -1.72 & * & -0.010 & -2.15 & ** & -0.010 & -2.20 & $* *$ & -0.010 & -2.04 & $* *$ \\
\hline SIZE & -0.012 & -9.10 & $* * *$ & -0.012 & -9.19 & $* * *$ & -0.012 & -8.99 & $* * *$ & -0.012 & -9.13 & $* * *$ \\
\hline LEV & 0.109 & 10.19 & $* * *$ & 0.115 & 10.57 & $* * *$ & 0.115 & 10.62 & $* * *$ & 0.113 & 10.49 & $* * *$ \\
\hline ROA & -0.026 & -0.67 & & 0.000 & 0.00 & & -0.002 & -0.05 & & -0.009 & -0.24 & \\
\hline MTB & -0.009 & -7.89 & $* * *$ & -0.011 & -9.23 & $* * *$ & -0.011 & -9.06 & $* * *$ & -0.011 & -8.76 & $* * *$ \\
\hline BETA & 0.005 & 1.03 & & 0.001 & 0.25 & & 0.001 & 0.30 & & 0.002 & 0.54 & \\
\hline DA & 0.022 & 0.95 & & 0.018 & 0.77 & & 0.015 & 0.63 & & 0.018 & 0.78 & \\
\hline FORN & 0.010 & 0.83 & & 0.016 & 1.39 & & 0.016 & 1.38 & & 0.014 & 1.20 & \\
\hline OWN & 0.004 & 0.40 & & 0.011 & 1.09 & & 0.011 & 1.04 & & 0.009 & 0.85 & \\
\hline Fixed effect & & & & & & Indu & and Year & & & & & \\
\hline Adj R2 & & 0.258 & & & 0.285 & & & 0.278 & & & 0.274 & \\
\hline $\mathrm{N}$ & & 1403 & & & 1403 & & & 1403 & & & 1403 & \\
\hline
\end{tabular}

(1) Please see Table 2 for variable definitions. (2) ${ }^{* * *}, * *$ and ${ }^{*}$ Indicate statistical significance at the $0.01,0.05$ and 0.10 levels, respectively. 


\subsubsection{Additional Analyses}

Table 6 shows the results of analyzing the relationship between company reputation and implied cost of capital based on a one-to-one sample based on the size of the company. Looking at the sample selection, 231 companies with corporate reputations and 1522 companies with no reputation were analyzed. As the result of the study may appear in the difference in the number of samples analyzed, similar sized companies were analyzed by matching industry and year one-to-one. As shown in Table 6, company reputation was found to be significantly negatively related to all four implied cost of capital measures (t-statistic $-1.94,-2.46,-2.62$ and -2.35 for COCPEG, COCMPEG, COCGM and COCAVG, respectively). It was found that the Hypothesis 1 was supported even if it was analyzed considering the size of the company.

Table 6. The effect of company reputation on the implied cost of equity.

\begin{tabular}{|c|c|c|c|c|c|c|c|c|c|c|c|c|}
\hline \multirow{3}{*}{$\begin{array}{l}\text { Variables } \\
\text { Intercept }\end{array}$} & \multicolumn{3}{|c|}{$\mathrm{COC}_{\mathrm{PEG}}$} & \multicolumn{3}{|c|}{ COC $_{\text {MPEG }}$} & \multicolumn{3}{|c|}{$\mathrm{COC}_{\mathrm{GM}}$} & \multicolumn{3}{|c|}{$\mathrm{COC}_{\mathrm{AVG}}$} \\
\hline & \multirow{2}{*}{$\begin{array}{c}\text { Estimate } \\
0.219\end{array}$} & \multicolumn{2}{|c|}{ t-Stat } & \multirow{2}{*}{$\begin{array}{c}\text { Estimate } \\
0.226\end{array}$} & \multicolumn{2}{|c|}{ t-Stat } & \multirow{2}{*}{$\begin{array}{c}\text { Estimate } \\
0.224\end{array}$} & \multicolumn{2}{|c|}{ t-Stat } & \multirow{2}{*}{$\begin{array}{c}\text { Estimate } \\
0.223\end{array}$} & \multicolumn{2}{|c|}{ t-Stat } \\
\hline & & 4.17 & $* * *$ & & 4.20 & $* * *$ & & 4.14 & $* * *$ & & 4.18 & $* * *$ \\
\hline REPUTATION & -0.009 & -1.94 & $*$ & -0.011 & -2.46 & $* *$ & -0.012 & -2.62 & $* * *$ & -0.011 & -2.35 & $* *$ \\
\hline SIZE & -0.007 & -3.17 & $* * *$ & -0.007 & -3.17 & $* * *$ & -0.007 & -3.12 & $* * *$ & -0.007 & -3.16 & $* * *$ \\
\hline LEV & 0.075 & 4.76 & $* * *$ & 0.089 & 5.54 & $* * *$ & 0.090 & 5.57 & $* * *$ & 0.084 & 5.31 & $* * *$ \\
\hline ROA & -0.039 & -0.76 & & -0.013 & -0.24 & & -0.016 & -0.31 & & -0.023 & -0.44 & \\
\hline МТВ & -0.005 & -2.95 & $* * *$ & -0.006 & -3.95 & $* * *$ & -0.006 & -3.84 & $* * *$ & -0.006 & -3.59 & $* * *$ \\
\hline BETA & 0.015 & 2.19 & $* *$ & 0.010 & 1.47 & & 0.009 & 1.27 & & 0.011 & 1.65 & $*$ \\
\hline DA & 0.014 & 0.43 & & 0.012 & 0.36 & & 0.014 & 0.40 & & 0.013 & 0.40 & \\
\hline FORN & -0.010 & -0.60 & & 0.005 & 0.29 & & 0.006 & 0.33 & & 0.000 & 0.01 & \\
\hline OWN & -0.008 & -0.52 & & 0.005 & 0.31 & & 0.003 & 0.21 & & 0.000 & 0.00 & \\
\hline Fixed effect & \multicolumn{12}{|c|}{ Industry and Year } \\
\hline Adj R2 & \multicolumn{3}{|c|}{0.291} & \multicolumn{3}{|c|}{0.293} & \multicolumn{3}{|c|}{0.290} & \multicolumn{3}{|c|}{0.291} \\
\hline $\mathrm{N}$ & \multicolumn{3}{|c|}{462} & \multicolumn{3}{|c|}{462} & \multicolumn{3}{|c|}{462} & \multicolumn{3}{|c|}{462} \\
\hline
\end{tabular}

(1) Please see Table 2 for variable definitions. (2) ${ }^{* * *},{ }^{* *}$ and ${ }^{*}$ Indicate statistical significance at the $0.01,0.05$ and 0.10 levels, respectively.

\section{Conclusions}

A company's reputation is an important factor influencing its sustainability and sustainability management. Numerous companies use sustainability as an indicator of corporate management, and thus strive to increase their company reputation. This study examined the relationship between corporate reputation and implied cost of capital by using the brand value representing sustainability from a consumer's perspective. Additionally, it examined whether the relationship between company reputation and implied cost of capital varies depending on the degree of tax avoidance.

As a result of empirical analysis, company reputation and implied cost of capital showed a significant negative relationship. The higher the company's reputation, the less information asymmetry in the stock market, indicating that the implied cost of capital decreases. The higher the company's reputation, the higher the company's sustainability, which means lower financing costs. Significant negative relationship between company reputation and implied cost of capital was not found in a group that was aggressive in tax avoidance. This is interpreted as weakening the significant negative relationship between company reputation and implied cost of capital due to aggressive tax avoidance that causes opacity of the information environment and creates information asymmetry related to corporate reputation.

The contributions and limitations of this study are as follows. First, in the context of lack of research in Korea that looked at the relationship between company reputation and implied cost of capital, we presented the empirical result that company reputation and implied cost of capital are negatively related. It is expected to provide useful information for follow-up studies by empirically showing the importance of company reputation in the stock market. Second, in addition to the use of Korean companies in the empirical analysis, the relationship between company reputation and implied cost of capital was additionally verified by dividing into active tax avoidance group and non-tax avoidance group to differentiate it from the study of Cao et al. (2015) [6]. Prior studies have 
been expanded in consideration of tax avoidance in relation to company reputation and implied cost of capital. The hypothesis we looked at further was not conducted in other studies and was not validated in previous studies. It shows that the relationship between company reputation and implied cost of capital can be changed according to tax avoidance. Third, according to the analysis results that the higher the reputation, the lower the implied cost of capital, it indicates that companies with a reputation have an advantage in raising capital. Suggesting to management and the board how to increase brand value for financing. It demonstrates the benefits that companies can achieve through sustainable management by maintaining a good reputation. The limitation of this study is that in estimating the implied capital cost, the sampling process is limited because financial analysts are only targeting companies that provide revenue forecasting information.

Author Contributions: Conceptualization, I.K. and J.K. (Jinsoo Kim); Formal analysis, J.K. (Jinsoo Kim); Methodology, I.K.; Investigation, J.K. (Jeongyeon Kang); Data Curation, J.K. (Jeongyeon Kang); Writing-original draft, I.K. and J.K. (Jinsoo Kim); Writing-review and editing, I.K. and J.K. (Jeongyeon Kang). All authors have read and agreed to the published version of the manuscript.

Funding: This research was supported by Daegu University Research Grant, 2020.

Conflicts of Interest: The authors declare no conflict of interest.

\section{References}

1. Wilson, R. Reputations in games and markets. In Game-Theoretic Models of Bargaining; Cambridge University Press: Cambridge, UK, 1985; ISBN 9780521267571.

2. Larcker, D.F.; Richardson, S.A. Fees paid to audit firms, accrual choices, and corporate governance. J. Account. Res. 2004, 42, 625-658. [CrossRef]

3. Jackson, A. Trade generation, reputation and sell-side analysts. J. Financ. 2005, 60, 673-717. [CrossRef]

4. Cowen, A.; Groysberg, B.; Healy, P. Which types of analyst firms are more optimistic? J. Account. Econ. 2006, 41, 119-146. [CrossRef]

5. Anginer, D.; Warburton, A.J.; Yildizhan, C. Firm Reputation and Cost of Debt Capital. MPRA. 2015. Available online: https://mpra.ub.uni-muenchen.de/id/eprint/64965 (accessed on 27 November 2020).

6. Cao, Y.; Myers, L.A.; Myers, L.A.; Omer, T.C. Company reputation and the cost of equity capital. Rev. Account. Study 2015, 20, 42-81. [CrossRef]

7. Balakrishnan, K.; Blouin, J.; Guay, W. Tax Aggressiveness and Corporate Transparency. Account. Rev. 2019, 94, 45-69. [CrossRef]

8. Easton, P. PE ratios, PEG ratios, and estimating the implied expected rate of return on equity capital. Account. Rev. 2004, 79, 73-95. [CrossRef]

9. Gode, D.; Mohanram, P. Inferring the cost of capital using the Ohlson-Juettner model. Rev. Account. Stud. 2003, 8, 399-431. [CrossRef]

10. Goh, B.W.; Lee, J.; Lim, C.Y.; Shevlin, T. The effect of corporate tax avoidance on the cost of equity. Account. Rev. 2016, 91, 1647-1670. [CrossRef]

11. Lambetr, R.; Leuz, C.; Verrecchia, R.E. Accounting Information, Disclosure, and the Cost of Capital. J. Account. Res. 2007, 45, 385-420. [CrossRef]

12. Frank, M.; Lynch, L.; Rego, S. Tax reporting aggressiveness and its relation to aggressive financial reporting. Account. Rev. 2009, 84, 467-496. [CrossRef]

13. Cook, K.A.; Moser, W.J.; Omer, T.C. Tax avoidance and ex ante cost of capital. J. Bus. Financ. Account. 2017, 44,1109-1136. [CrossRef]

14. Graham, J.; Hanlon, M.; Shevlin, T.; Shroff, N. Incentives for tax planning and avoidance: Evidence from the field. Account. Rev. 2014, 89, 991-1023. [CrossRef]

15. Gallemore, J.; Maydew, E.; Thornock, J. The reputational costs of tax avoidance. Contemp. Account. Res. 2014, 31, 1103-1133. [CrossRef]

16. Dyreng, S.; Hoopes, J.; Wilde, J. Public pressure and corporate tax behavior. J. Account. Res. 2016, 54, 147-186. [CrossRef]

17. Austin, C.; Wilson, R. An examination of reputational costs and tax avoidance: Evidence from firms with valuable consumer brands. J. Am. Tax. Assoc. 2017, 39, 67-93. [CrossRef] 
18. Choi, T.H. Do Ethical Companies Have Lower Implied Cost of Equity Capital? Evidence from the Korean Stock Market. Asian Bus. Manag. 2012, 11, 219-246. [CrossRef]

19. Lim, Y.D. Tax avoidance, cost of debt and shareholder activism: Evidence from Korea. J. Bank. Financ. 2011, 35, 456-470. [CrossRef]

20. Podhorska, I.; Gajanova, L.; Kliestikova, J.; Popescu, G.H. Analysis of Internally Generated Goodwill Indicators: A Case Study of the Slovak Republic. Organizacija 2019, 52, 271-285. [CrossRef]

21. Podhorska, I.; Valaskova, K.; Stehel, V.; Kliestik, T. Possibility of company goodwill valuation: Verification in Slovak and Czech Republic. Manag. Mark.-Chall. Knowl. Soc. 2019, 14, 338-356. [CrossRef]

22. Kliestik, T.; Kovacova, M.; Podhorska, I.; Kliestikova, J. Searching for Key Sources of Goodwill Creation As new Global Managerial Challenge. Pol. J. Manag. Stud. 2018, 17, 144-154. [CrossRef]

23. Merton, R.C. A simple model of capital market equilibrium with incomplete information. J. Financ. 1987, 42, 483-510. [CrossRef]

24. Cao, Y.; Myers, L.A.; Omer, T.C. Does company reputation matter for financial reporting quality? Evidence from restatements. Contemp. Account. Res. 2012, 29, 956-990. [CrossRef]

25. Francis, J.R.; Lafond, R.; Olsson, P.; Schipper, K. Cost of equity and earnings attributes. Account. Rev. 2004, 79, 967-1010. [CrossRef]

26. Ohlson, J.; Juettner-Nauroth, B. Expected EPS and EPS growth as determinants of value. Rev. Account. Stud. 2005, 10, 349-365. [CrossRef]

27. Dyreng, S.; Hanlon, M.; Maydew, E. Long-run corporate tax avoidance. Account. Rev. 2008, 83, 61-82. [CrossRef]

28. Donohoe, M.; Knechel, W. Does Corporate Tax Aggressiveness Influence Audit Pricing? Contemp. Account. Res. 2014, 31, 284-308. [CrossRef]

Publisher's Note: MDPI stays neutral with regard to jurisdictional claims in published maps and institutional affiliations. 